International Journal of Engineering \& Technology, $7(2.31)(2018) 235-237$
International Journal of Engineering \& Technology
SPC
Website: www.sciencepubco.com/index.php/IJET
Research paper

\title{
Quality of life of software employees with reference to Kannur, Kerala
}

\author{
Sreelal $^{1 *}$, G. Godanavalli \\ ${ }^{1}$ Research Scholar, Department of Social Work, Karpagam Academy of Higher Education, Coimbatore. \\ ${ }^{2}$ Assistant Professor, Department of Social Work, Karpagam Academy of Higher Education, Coimbatore. \\ *Corresponding author E-mail:ranjitlingaraj@gmail.com
}

\begin{abstract}
Indian Information technology sector is one of the largest sectors which significantly contributes the economy of the country. The problems associated with the nature of job arises the question on the satisfaction of the employees on their life or quality of life. Thus the present study focuses on the quality of life of the software employees and the factors influencing the quality of life of the software employees. The results show that quality of life of the software employees was moderate and demographic variables namely age, gender, place of living, monthly income and years of experience influences the quality of life of the software employees. The suggestion for enhancing the quality of life of the software employees are discussed in the article.
\end{abstract}

Keywords: Information technology (IT), software, quality of life.

\section{Introduction}

The Indian information technology contributes significantly to the economy of the country by increasing the GDP and the current project "Digital India" also help in the development of the IT sector in India. Large number of youngsters is attracted towards the industry as it provides an attractive package, flexi work timings, social status, welfare services, growth and carrier opportunities, etc. Thus, every year lakhs of young graduates from different disciplines get in to this sector for employment. At the same time, the industry has its other face which is associated with stress and strain. The nature of work in the IT sector is challenging and stressful due to targets, deadlines, work pressures, non-stop working hours, nightshifts, etc. Thus, these leads to various health problems like neck pain, back pain, repetitive strain injuries, etc due to bad sitting postures and sitting in front of computers for long hours. It also causes social problems like marital disputes between couples, isolation, relationship issues, etc. Literatures show that these employees even go the extent of committing suicide because of their nature of job. While considering the above said points, there arises a question "Does these employees have a life satisfaction or quality of life?. Quality of life is the general well-being of individuals and societies. It includes the satisfaction on health, wealth, education, employment, religious beliefs, finance, etc. Thus, this study is an attempt to understand the level of quality of life of the software employees and the factors influencing their quality of life.

\section{Review of literature}

The literatures shows that job stress was found to be significantly related to the quality of life of software employees. The study also found that personal variables like age, gender, education, marital status, etc are significantly associated with the quality of life of software employees (Ranjit and Mahespriya, 2013). Another study found that the socio-economic characteristics namely as age and education showed no significant association with the quality of life. The study concludes that stress is the most influencing factor of quality of life. (Baune. B.T and Aljeesh. Y, 2006). A study results show that social support was found a significant positive relationship with the quality of life of the employees. Increase the social support in the organizations will increase the level of quality of life of the employees. A research study showed that out of the eight predictors included in the study, which includes religion, job stress, job passion, employment status, fatigue, sleep quality, family function, and drug use, explained 34 percent of variance in the quality of life of the employees. When demographics are controlled, the analysis showed that three variables namely sleep quality, fatigue and family function explained $21 \%$ of variance in the quality of life of the employees (Chung, Chi-Ti; Chung, Ue-Lin, 2009).

\section{Objective of the study}

1. To study the demographic profile of the software employees.

2. To assess the level of quality of life of the software employees.

3. To examine the influence of demographic variables on the level of quality of life of the software employees.

\section{Methodology}

The research has adopted descriptive research design in the present study. The software employees working in the Information Technology (IT) companies in Kannur District of Kerala State are taken as the universe for the present study. Snow ball sampling technique was used to select the samples for the study as it was practically very difficult to select the respondents through others means of sampling. A total of 416 software employees was taken as sample in the present study based on D.Morgens sample size determination table. Questionnaire method was used in the study 
to collect data from the selected employees which consists of two parts namely demographic profile and quality of life. Standardized quality of life scale (5 point scale) was used to assess the level of quality of life of the employees.

The Cornbach's Alpha value shows a reliability value of 0.72 for the quality of life scale.

The data was analyzed using mean, standard deviation, coefficient of correlation, ANOVA, principal component analysis and Friedman's test.

\section{Analysis and interpretation}

Table 1: Personal Details of the Respondents

\begin{tabular}{|c|c|c|c|}
\hline Variables & Particulars & $\begin{array}{c}\text { No. of } \\
\text { Respondents }\end{array}$ & Percentage \\
\hline \multirow[t]{4}{*}{ Age } & Below 25 & 284 & 68.3 \\
\hline & $26-30$ & 122 & 29.3 \\
\hline & $31-35$ & 4 & 1.0 \\
\hline & 36 and above & 6 & 1.4 \\
\hline \multirow[t]{2}{*}{ Gender } & Male & 152 & 36.5 \\
\hline & Female & 264 & 63.5 \\
\hline \multirow[t]{3}{*}{ Marital Status } & Married & 34 & 8.2 \\
\hline & Unmarried & 380 & 91.3 \\
\hline & Loss of Partner & 2 & .5 \\
\hline \multirow{5}{*}{$\begin{array}{l}\text { Monthly } \\
\text { income }\end{array}$} & Below Rs.10000 & 328 & 78.8 \\
\hline & Rs.10001-15000 & 66 & 15.9 \\
\hline & Rs.15001-20000 & 14 & 3.4 \\
\hline & Rs.20001-25000 & 2 & .5 \\
\hline & $\begin{array}{l}\text { Rs.25001 and } \\
\text { above }\end{array}$ & 6 & 1.4 \\
\hline \multirow{4}{*}{$\begin{array}{c}\text { Years of } \\
\text { experience }\end{array}$} & Below 1 year & 210 & 50.5 \\
\hline & $1-2$ years & 166 & 39.9 \\
\hline & 3-4 years & 24 & 5.8 \\
\hline & 5 years and above & 16 & 3.8 \\
\hline \multirow[t]{3}{*}{ Role of Job } & Managerial & 16 & 3.8 \\
\hline & $\begin{array}{c}\text { Level of a Team } \\
\text { Leader }\end{array}$ & 48 & 11.5 \\
\hline & $\begin{array}{l}\text { Functioning } \\
\text { Professionals }\end{array}$ & 352 & 84.6 \\
\hline
\end{tabular}

The table 1 depicts that $68.3 \%$ of the respondents belong to the age below 25 years, $29.3 \%$ of the them belong to $26-30$ years. It shows that $63.5 \%$ of the respondents are female and rest are male. Majority $91.3 \%$ were unmarried, $8.2 \%$ of them were married, majority of them are earning an income below Rs. 10,000, $50.5 \%$ of them had work experience below 1 year, $39.9 \%$ of them had work experience between 1-2 years, $5.8 \%$ of them had work experience between 3-4 years and 3.8 \% of them had experience of 5 years and above.

Majority of the respondents (84.6 percent) were functioning professionals, 11.5 percent of them were in the level of team leaders and 3.8 percent of them were in the managerial cadre.

Table 2: Level of Quality of Life of the Respondents

\begin{tabular}{|c|c|c|}
\hline Level of Quality of Life & Frequency & Percent \\
\hline High (90-120) & 62 & 14.9 \\
\hline Moderate (71-89) & 304 & 73.1 \\
\hline Low (24-70) & 50 & 12.0 \\
\hline Total & $\mathbf{4 1 6}$ & $\mathbf{1 0 0 . 0}$ \\
\hline
\end{tabular}

The table 2 shows that majority of the respondents ( 73.1 percent) had a moderate level of quality of life, $14.9 \%$ of them had a high level of quality of life and $12 \%$ of them had a moderate level of quality of life.

The basic needs essential for a family need more food, materials, clothing, living and sleeping room and health and education. It is difficult to fulfil the basic needs of a family such as food, clothing, housing, with available resources if the size of a family is large. Quality of life stars to degrade.

This low quality of life in a family will have to negative effect on physical, mental and intellectual development of family members.
Table 3: Influence of Demographic Variables on the Level of Quality of life of the Respondents

\begin{tabular}{|c|c|c|c|}
\hline Variable & Test & Value & Result \\
\hline Age & Correlation & $\mathrm{r}=-0.128 \mathrm{p}<0.05$ & Significant \\
\hline Gender & t-test & $\mathrm{t}=2.108 \mathrm{P}<0.05$ & Significant \\
\hline Marital status & ANOVA & $\mathrm{F}=1.439 \mathrm{P}>0.05$ & Not Significant \\
\hline Type of family & $\mathrm{t}$-test & $\mathrm{t}=4.104 \mathrm{P}<0.05$ & Significant \\
\hline Monthly Income & Chi-square & $\mathrm{Chi}=32.630 \mathrm{P}<0.01$ & Significant \\
\hline Years of experience & Chi-square & $\mathrm{Chi}=12.856 \mathrm{P}<0.05$ & Significant \\
\hline Role of job & ANOVA & $\mathrm{F}=1.566 \mathrm{P}>0.05$ & Not Significant \\
\hline
\end{tabular}

The coefficient of correlation value $(r=-0.128)$ reveals that there is a significant relationship between age of the respondents and level of quality of the respondents at 0.05 level. The t-test value shows that $(\mathrm{t}=2.108)$ there is a significant difference in the level of quality of life among the male and female respondents at 0.05 level. The mean value shows that male respondents had better quality of life than their counterparts. The ANOVA value $(\mathrm{F}=1.439)$ shows that there is no significant difference in the level of quality of life among married, unmarried and widowed respondents at 0.05 level. The $t$-test value $(t=4.104)$ shows that there is a significant difference in the level of quality of life among nuclear family and joint family respondents at 0.05 level. The mean value shows that nuclear family respondents had better quality of life compared to joint family respondents. The chisquare value shows that there is a significant association between monthly income and level of quality of life at 0.05 level. It is inferred that higher the income, higher is the level of quality of life and vice versa. The chi-square value shows that there is a significant association between experience and level of quality of life at 0.05 level. It is inferred that higher the experience higher is the level of quality of life and vice versa. The ANOVA value ( $\mathrm{F}=$ 0.325 ) shows that there is no significant association between job role and level of quality of life of the respondents.

\section{Salient findings}

- More than three fourth $(68.3 \%)$ of the respondents belong to the age below 25 years.

- More than three fourth $(63.5 \%)$ of the respondents are female

- $\quad$ Majority $(91.3 \%)$ of the respondents were unmarried.

- Majority of the respondents are earning an income below Rs. 10,000 per month

- More than half $(50.5 \%)$ of them had work experience below 1 year

- Majority of the respondents (84.6 percent) job role was professionals.

- The demographic variables namely age, gender, type of family, monthly income and experience influences the level of quality of life of the respondents.

\section{Suggestions}

Health related awareness has to be provided, to make the software employees to be cautious on the occupational related disease and other health hazards. Skilled based training can be given to the new comers for improving the performance and to reduce the job stress which will increase their quality of life as stress is an important factor which influences quality of life. The issues like affection, belongingness, warmth \& friendly atmosphere, recognition, self-growth, self-fulfillment are gaining more and more popularity and importance. So, these issues should be given due attention by the management. For achieving a high productivity and quality of the product, the employees has to be provided with conductive work culture with frequent brake and holidays. Workers have to be given more openings and opportunities for their career developments which will induce the job satisfaction of the employees which in turn enhances their satisfaction of life. The study suggests the management to take the necessary steps to arrest the drift of deteriorating quality of life in 
certain human factors like experience, wealth position, family size which are the basic factors to express the workers desire. Improvements or modifications are required in the field of recreation facilities; leave fair, safety equipments, overtime payments, compensatory arrangements on medical grounds, promotion etc. Modifications shall be initiated in the field of grievance handling, service awards and other motivation etc.

\section{Conclusion}

The Indian software industry is remarkable in a number of respects. It is service rather than product oriented, heavily export oriented, and is largely managed by professional and entrepreneurial managements. The present study concludes that moderate level of quality of life was found among the software employees. The study also concludes that the demographic variables namely age, gender, monthly income, years of experience do influence the quality of life of the software employees.

\section{Reference}

[1] Chung CT \& Chung UL, "An exploration of quality of life and related factors among female flight attendants", Journal of Nursing Research, Vol.17, No.3, (2009), pp.212-220.

[2] Baune BT \& Aljeesh Y, "The association of psychological stress and health related quality of life among patients with stroke and hypertension in Gaza Strip", Annals of General Psychiatry, Vol.5, No.6, (2006).

[3] Imhonde HO, Idiakheua EO \& Ewanbhorshiora OF, "Quality of life among female workers in edo state: consideration of job-type, age and marital status", Gender and Behaviour, Vol.8, No.1, (2010), pp.2846-2856.

[4] Tamara S, U.S. Workers Hate Their Jobs More Than Ever. INC Magazine, (2007).

[5] Trompenaars FJ, Masthoff ED, Van Heck GL, Hodiamont PP \& De Vries J, "Relationships between demographic variables and quality of life in a population of Dutch adult psychiatric outpatients", Social psychiatry and psychiatric epidemiology, Vol.40, No.7, (2005), pp.588-594.

[6] Gopinathan V \& Velmurugan R, "A study on the service quality of the primary agricultural co-operative societies", International Journal of Commerce and Management Research, Vol.2, No.12, (2013), 99-101.

[7] Sumathi V \& Velmurugan R, "Quality of work life of employees in private companies with reference to Coimbatore", International Journal of Multidisciplinary Research and Development, Vol.4, No.5, (2013), pp.128-131.

[8] William D, "Low income, more stress", Pittsburgh Business Times, (2006).

[9] Yu-Ju Y, "Job satisfaction and quality of life among hospital nurses in the Yunlin-Chiayi area", The Journal of Nursing, Vol.55, No.2, (2008), pp.29-38. 